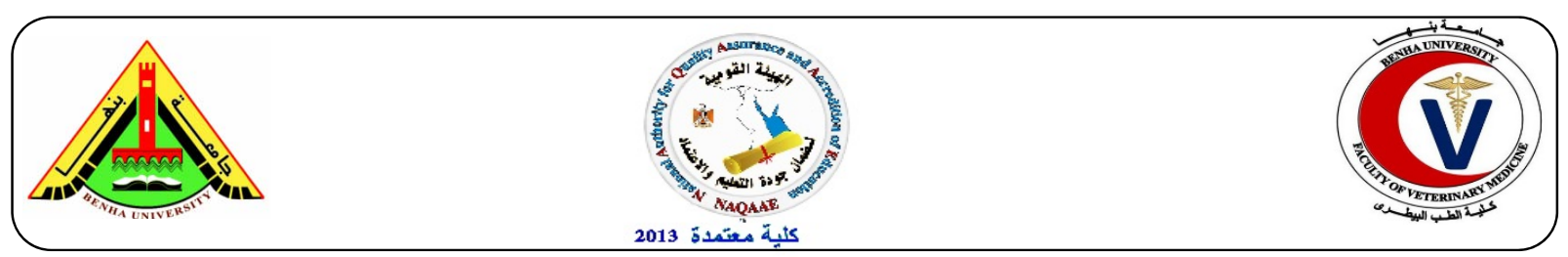

\title{
Protective impacts of Cupressus sempervirens leaves extracts against paracetamol hepatotoxicity
}

\author{
Ahmed A. Salman', Ibrahim M. Abd El-Aleem ${ }^{1}$, Ahmed A. Abd-El Rahman ${ }^{1}$, Tarek S. \\ Elhusseini $^{2}$, Abd Allah E. El-Hadary ${ }^{1}$ \\ ${ }^{1}$ Biochemistry Dept. Fac. Agric., Benha University, Egypt \\ ${ }^{2}$ General surgery and liver transplantation Dept. Fac. Of Medicine. Mansoura University, Egypt
}

\begin{abstract}
A B S T R A C T
The main objective of this study is to evaluate the antioxidant activity of Cupressus sempervirens leaves extract invitro and rat model in which paracetamol was used to induce hepatic damage. The antioxidant and anti-quorum sensing activities of eight extracts were studied. Total phenolic compounds and scavenging radical effect on 2, 2diphenylpicrylhydrazyl (DPPH) were investigated, (the specific phenolic and flavonoid composition quantification for hydrolyzed ethyl acetate fraction $\mathrm{pH} 4$ were performed by HPLC E-vanilic, Alpha-coumaric, Salicylic and Ferulic were found as the major phenols. Narengin, Hisperidin, Quercetrin and Hispertin were found as the major flavonoids. Biological experiment was carried out for thirty days. Results revealed that a significant increase in serum ALT, AST, ALP, Total bilirubin, TG, Total cholesterol, (LDLC) and nitric oxide in rats treated with paracetamol. However administration of Cupressus sempervirens in paracetamol induced liver toxicity in rats exhibited a significant decrease in all mentioned parameters on the other hand a significant decrease in serum total protein albumin concentration, (HDLC), Catalase, glutathione peroxidase (GPx), Glutathione -S-transferase (GST) and Glutathione reduced were observed in paracetamol induced hepatic toxicity in rats when compared with control normal group. Meanwhile Cupressus sempervirens leaves resulted in significant in all mentioned parameter and when enhanced the activity of antioxidant enzymes in liver tissue. It could be concluded that, inhibition of peroxidation, inflammation and oxidative stress and enhanced antioxidant status in rat liver tissue by Cupressus sempervirens suggest the potential efficacy of Cupressus sempervirens as an addition Hepatoprotective, anti-inflammatory and anti-hepatotoxic agent in treatment of liver toxicity
\end{abstract}

KEYWORDS: Cupressus sempervirens leaves, Antioxidant, hepatoprotective, paracetamol.

(http://www.bvmj.bu.edu.eg)

(BVMJ-32(1): 41 -49, 2017)

\section{INTRODUCTION}

Liver is considered to be highly sensitive to toxic agents. It's also one of the hardest working organ in living system and can re-grow its own tissue. It can work when a large portion of it is removed or diseased. It participates in variety of metabolic activities and thus may exposed to many toxicants, chemical and drugs which could injure it (Rao and Das, 2014). It is the body metabolic clearing house as its smooth endoplasmic reticulum is capable for dealing with both endogenous chemicals like cholesterol, fatty acids, hormones specially steroids and proteins, as well as exogenous ones as alcohol and drugs. For that liver is regularly subjected to toxic harmful injury (Om, 2011). Paracetamol (acetaminophen) is the most widely used over-the-counter analgesic and overdosing with paracetamol is the leading cause of hospital admission for acute liver failure. 5Lipoxygenase (5-LO) catalysis arachidonic acid to form Long Term Support, which lead to inflammation and oxidative stress. Cupressus sempervirens belongs to kingdom: Plantae, class: Pinopsida, order: Pinales and family Cupressaceae, is a tall tree (usually $15-20 \mathrm{~m}$. high but can reach $30-40 \mathrm{~m}$.) with a well-developed trunk (may be $3 \mathrm{~m}$. in circumference); grows quickly until the age of 20 years. Cupressus sempervirens leaves are dark green, either acicular (in young stages) or very small, scale-like and overlapping in four ranks. It is distributed in Egypt, North Libya, Greece, Turkey, Syria, Lebanon and Western Jordan (Emami et al., 2009; Zeinab et al., 2012) found that the concentration of phenolic and flavonoids in Cupressus sempervirens are $86.3 \pm 2.47 \mu \mathrm{g}$ GAE$/ \mathrm{mg}$ extract and $26.4 \pm 0.94 \mu \mathrm{g}$ $\mathrm{RE} / \mathrm{mg}$ extract, respectively. The main constituents of Cupressus sempervirens include several phenolic compounds (anthocyanidin, 
catechines, flavones, flavonols and iso flavones) tannins (ellagic acid, gallic acid, phenyl isopropanoids, caffeic acid, coumaric acid and ferulic acid) lignans, catechol and essential oil (Kassem et al., 1991)

Therefore, this research aims to evaluate the antioxidant activity of Cupressus sempervirens leaves extract in vitro and rat model in which paracetamol was used to induce hepatic damage

\section{MATERIALS AND METHODS}

2.1. Cupressus sempervirens leaves were obtained from farm of Faculty of Agriculture-Benha University.

\subsection{Chemicals and reagents:}

Paracetamol and silymarin were provided as gifts from Sedico Pharmaceutical Company, Egypt. Diphenylpicrylhydrazyl (DPPH) chemical reagent $\left(\right.$ Aldrich $\left.^{\circledR}\right)$, Folin-ciocalteu reagent $\left(\right.$ Sigma $\left.^{\circledR}\right)$. Diagnostic kits were obtained from Bio Meriêuex Laboratory Reagents and Products, France.

\subsection{Preparation of extracts /fractions:}

To prepare unhydrolyzed and hydrolyzed samples of Cupressus sempervirens leaves, $1000 \mathrm{~g}$ powder for each were extracted by adding $2.5 \mathrm{~L}$ ethanol containing $6 \mathrm{~N} \mathrm{HCl}(1 \%)$ and Hydrolysis, sample reflux $2 \mathrm{~h}$ at water bath and room temperature. Both supernatants were recovered after filtering through Whatman No. 1 filter paper. Then the respective solvents from the supernatants were evaporated in a vacuum rotary evaporator (Eyela $\mathrm{N}-\mathrm{N}$ series, Tokyo, Japan) at $40^{\circ} \mathrm{C}$ to have unhydrolyzed crude extract (UCE) and hydrolyzed crude extract (HCE). To obtain unhydrolyzed ethyl acetate fraction (UEF) and hydrolyzed ethyl acetate fraction (HEF), both crude extracts were partitioned in double distilled water and ethyl acetate.

The aqueous parts were treated with $20 \%$ $\mathrm{NaHCO}_{3}$ to change the $\mathrm{pH}$ to 8 , which converts the phenolic to their sodium salts leaving behind the impurities or non-phenolic. To obtain HEF (pH 8) and UEF ( $\mathrm{pH} 8$ ), both fractions were extracted with ethyl acetate. The $\mathrm{pH}$ of aqueous parts was changed to 4 by adding $6 \mathrm{~N} \mathrm{HCl}$ and again extracted with ethyl acetate to obtain HEF (pH 4) and UEF pH 4). Thus, obtained eight extract/fraction UCE, HCE, UEF, HEF. UEF (pH 8), HEF (pH 8), UEF (pH 4), and HEF ( $\mathrm{pH} 4)$ were evaporated in a vacuum rotary evaporator to obtain the dry extracts (Singh et al., 2009).

\subsection{Determination of total Phenolic Contents.}

Total phenolic content was determined using Folin-Ciocalteu reagent with gallic acid as stander (Singleton and Rossi, 1965).

\subsection{Antiradical scavenging activity:}

Free radical activity of the Cupressus sempervirens leaves extract was determined using 2, 2-diphenylpicrylhydrazyl (DPPH) (Lee et al., 2002).

\subsection{HPLC analysis:}

The dried hydrolyzed ethyl acetate fraction (HEF) ( $\mathrm{pH} \mathrm{4)}$ were dissolved in HPLC grade methanol $1.0 \mathrm{mg} / \mathrm{mL}$ ), filtered through sterile 0.22 $\mu \mathrm{m}$ Millipore filter and subjected to qualitative and quantitative analysis by using Shimadzu LC-IOA (Kyoto, Japan) HPLC instrument. The instrument equipped with a dual-pump LC-1 OAT binary system (Shimsadzu, Kyoto, Japan) HPLC, a UV detector SPD-10A (Shimadzu, Kyato, Japan), and a Phenomenex Luna RP, C 18 column (4.6 s 250 $\mathrm{mm})$. Data were integrated by Shimadzu Class VP series software (Shimadzu, Kyota, Japan). Separation was achieved with an acetonitrile/ water containing $1 \%$ acetic acid linear gradient program, started with $18 \%$ acetonitrile. Changing to $32 \%$ in $15 \mathrm{~min}$ and finally to $50 \%$ in $40 \mathrm{~min}$. Results were obtained by comparison of peak areas $(\lambda \max =254$ $\mathrm{nm}$ ) of the samples (mg/g dry extract) with that of standards (Prakash et al., 2007).

\subsection{Experimental animals}

The experimental animals were healthy adult male albino rats (Wister Strain) of approximately same age, each weighing 120 to $140 \mathrm{~g}$, purchased from the farm of the Organization of Biological Products and Vaccines, Helwan, Egypt. Experimental procedures were conducted in conformity with the institutional guidelines and the Guidelines for Care and Use of Laboratory Animals in Biomedical Research of the WHO (World Health Organization). Animals were housed under ambient temperature of $25^{\circ} \mathrm{C}$ with 50 $\%$ relative humidity and a 12 -h light-dark cycle and allowed free access to water and fed on standard diet (Reeves et al., 1993).

\subsection{Experimental design:}

Thirty rats were used. There were divided into 5 treatments each treatment group consisted of 6 rats. Group 1: a negative control received basal diet. Group 2: a positive control was received paracetamol (three times a week) at a dose $750 \mathrm{mg} /$ $\mathrm{kg}$ b.w. Group 3: Was received paracetamol at a $750 \mathrm{mg} / \mathrm{kg}$ b.w, simultaneously administered 50 mg silymarin/ $\mathrm{kg} \mathrm{b.w}$. given orally through gastric gavages (three times a week) for 30 days. Group 4: 
Was received paracetamol at a $750 \mathrm{mg} / \mathrm{kg}$ b.w, simultaneously administered $100 \mathrm{mg}$ hydrolyzed ethyl acetate fraction (HEF) (pH 4) of Cupressus sempervirens extract/ $\mathrm{kg}$ b.w. given orally through gastric gavages (three times a week) for 30 days. Group 5: was received paracetamol at a $750 \mathrm{mg} / \mathrm{kg}$ b.w, simultaneously administered $200 \mathrm{mg} / \mathrm{kg}$ hydrolyzed ethyl acetate fraction (HEF) ( $\mathrm{pH} 4)$ of Cupressus sempervirens extract $/ \mathrm{kg}$ b.w. given orally through gastric gavages (three times a week) for 30 days.

\subsection{Biochemical blood analyses}

Blood samples were collected at the end of experiment obtained from the retro-orbital plexus veins from individual rats by means of fine capillary heparinized tubes, and were allowed to clot. Serum was separated by centrifugation at $3000 \mathrm{rpm}$ for $15 \mathrm{~min}$. and was used to investigate the biochemical parameters including function tests of liver and serum lipid profile. Determinations were done on activities of liver enzymes of alanine amino transaminase (ALT) aspartate amino transaminase (AST), alkaline phosphatase (ALP) as well as serum total protein and serum albumin (Reitman and Frankel, 1957; Tietz, 1983), (Doumas, 1975; Doumas et al., 1971). Globulin was calculated by subtracting the albumin from serum total protein. Lipid profile of total lipids (TL), triglycerides (TG), total cholesterol (TC), high density lipoprotein cholesterol (HDLC) and low density lipoprotein cholesterol (LDLC) were determined according to the methods reported by Fossati and Precipe (1982).

\subsection{Assessment of hepatic oxidative stress biomarkers}

Liver samples were washed immediately with ice-cold saline to remove excess blood. Liver tissue was homogenized in cold $0.1 \mathrm{M}$ potassium phosphate saline $(\mathrm{pH}=7.4)$ at extraction ratio of $1: 9$ $\mathrm{w} / \mathrm{v}$. The homogenate was centrifuged at $5000 \mathrm{rpm}$ for $10 \mathrm{~min}$ at $4{ }^{\circ} \mathrm{C}$, then the supernatant was analyzed for antioxidant markers. Glutathione peroxidase (Gpx), was measured spectrophotometrically by using Ellman's reagent "DTNB" (Moron et al., 1979). Glutathione-Stransferase activity was determined using aromatic substrate by monitoring change in absorbance due to thioether formation (Habig et al., 1974). Glutathione reduced adopted by Prins and Loos (1969). Catalase activity was determined by the method of Bock et al. (1980). Determinations were done of Nitric Oxide by the method of (Montgomery and Dymock, 1961).

\subsection{Statistical analysis}

All data were analyzed by one-way ANOVA and statistical analyses were performed using the statistical software SPSS 11.0 (SPSS Ltd., Surrey, UK). Ratio values were not arcsine transformed before statistical analysis (SAS, 1996).

\section{RESULTS}

Total phenolic compounds and antioxidant activity from the data presented in Table (1) it is clear that the DPPH scavenging activity of the eight Cupressus sempervirens leaves extract showed wide variation from $(8.75 \%$ to $95.43 \%)$. Total phenolic content expressed as mg gallic acid equivalents (GAE)/g extract of the eight Cupressus sempervirens leaves extracts showed wide variation from (10.31 to 112.41).

Table (1): Phenolic content (mg/g extract) and antiradical activities of Cupressus sempervirens leaves extracts.

\begin{tabular}{lcc}
\hline Material & $\begin{array}{c}\text { Total phenolic content mg gallic } \\
\text { acid equivalents(GAE/G) }\end{array}$ & \%Antiradical activity \\
\hline Unhydrolyzed crude extract & 43.23 & 36.70 \\
Hydrolyzed crude extract & 87.76 & 74.50 \\
Unhydrolyzed ethyl acetate fraction & 52.38 & 44.47 \\
Hydrolyzed ethyl acetate fraction & 92.49 & 78.50 \\
Unhydrolyzed ethyl acetate fraction (pH 8) & 10.31 & 8.75 \\
Hydrolyzed ethyl acetate fraction (pH 8) & 21.56 & 18.30 \\
Unhydrolyzed ethyl acetate fraction (pH 4) & 103.51 & 87.87 \\
Hydrolyzed ethyl acetate fraction (pH 4) & 112.41 & 95.43 \\
\hline
\end{tabular}




\subsection{Identification of some antioxidant components of Cupressus sempervirens leaves in hydrolyzed ethyl acetate fraction ( $\mathrm{pH} 4)$}

Data presented in table (2) showed the chemical constituents of the hydrolyzes ethyl acetate fraction (pH 4) of Cupressus sempervirens leaves. The tabulated data revealed the presence of 24 phenolic compounds and 10 flavonoids which could be identified in hydrolyzed ethyl acetate fraction $(\mathrm{pH}$ 4)

The results in table (2) revealed the presence of 24 phenolic compounds in hydrolyzed ethyl acetate fraction of Cupressus sempervirens leaves. The highest quantities were e-vaniliic (28889.16 $\mathrm{mg} / 100 \mathrm{~g})$, Alpha-coumaric (1943.08 mg/100 g), salicylic $(1359.05 \mathrm{mg} / 100 \mathrm{~g})$, Ferulic (1314.41 $\mathrm{mg} / 100 \mathrm{~g}), P-\mathrm{OH}$-benzoic $(1265.15 \mathrm{mg} / 100)$ pyrogallol $(1219.59 \mathrm{mg} / 100 \mathrm{~g})$ and vanillic $(1166.13 \mathrm{mg} / 100 \mathrm{~g})$. The results in table (3) revealed the presence of 10 flavonoids in hydrolyzed ethyl acetate fraction of Cupressus sempervirens leaves. The highest quantities were Narengin (9953.06 mg /100 gm), Hisperidin (1069.67 mg /100g) Quercetrin (966.37 mg /100 g), Hespertin (336.15 mg/100 g) and Rutin (206.32 $\mathrm{mg} / 100 \mathrm{~g})$.

3.2. Effect of Cupressus sempervirens administration on serum hepatic function test in normal and paracetamol induced hepatotoxicity in rats.

The obtained data in table (4) revealed a significant increase in ALT, AST, ALP, total bilirubin, direct bilirubin, total cholesterol, triglycerides and LDLC in paracetamol induced hepatotoxicity group accompanied with significant reduction in total protein, albumin, globulin and HDLC when compared with control normal group. While in group with Cupressus sempervirens there were significant decrease in ALT, AST, ALP, total bilirubin, direct bilirubin, total cholesterol, triglycerides and LDLC accompanied with significant increase in total protein, albumin, globulin and HDLC

3.3. Effect of Cupressus sempervirens leaves extract administration on liver tissue antioxidant enzymes (GSH, glutathione $-\mathrm{S}$ transferase, glutathione peroxidase and catalase activity and nitric oxide concentration normal and paracetamol induced hepatotoxicity in rats

The obtained data in table (5) revealed a significant increase in nitric oxide and significant decrease in $\mathrm{GSH}$, glutathione -S-transferase, glutathione peroxidase and catalase enzyme activities level in liver tissue homogenate in paracetamol induced hepatotoxicity group, when compared with control group while treated group with Cupressus sempervirens show significant decrease in nitric oxide and significant increase in GSH, glutathione -S-transferase, glutathione peroxidase and catalase enzymes activities level in liver tissue homogenate when compared with paracetamol treated group

Table (2): Phenolic compounds of hydrolyzed ethyl acetate fraction of Cupressus sempervirens leaves analyzed by HPLC

\begin{tabular}{lc}
\hline Phenolic compounds & $\begin{array}{c}\text { The results of phenolic } \\
\text { compounds (mg/100g) }\end{array}$ \\
\hline Gallic & 997.5 \\
Pyrogallol & 1219.59 \\
3-OH-Tyrosol & 1003.99 \\
4-Amino-benzoic & 171.59 \\
Protocatchuic & 820.72 \\
Chlorogenic & 1003.84 \\
Catechol & 367.48 \\
Catechein & 931.61 \\
Caffeine & 494.3 \\
P-OH-benzoic & 1265.15 \\
Caffeic & 347.76 \\
Vanillic & 1166.13 \\
Ferulic & 1314.41 \\
Iso-ferulic & 144.84 \\
e-vanillic & 28889.16 \\
Reversetrol & 109.14 \\
Ellagic & 259.35 \\
Alpha-coumaric & 1943.08 \\
Benzoic & 1165.03 \\
3,4,5-methoxy-cinnamic & 186.80 \\
Salycilic & 1359.05 \\
Coumarin & 59.62 \\
p-coumaric & 18.23 \\
Cinnamic & 28.02 \\
\hline
\end{tabular}

Table (3): Flavonoids compounds of hydrolysed ethyl acetate fraction of Cupressus sempervirens leaves analyzed by HPLC

\begin{tabular}{lc}
\hline Flavonoids & The results of flavonoids $(\mathrm{mg} / 100 \mathrm{~g})$ \\
\hline Narengin & 9953.06 \\
Rutin & 206.32 \\
Hesperidin & 1069.67 \\
Rosmarinic & 101.35 \\
Quercetrin & 966.37 \\
Quercetin & 198.65 \\
Kampferol & 69.13 \\
Hispertin & 336.15 \\
Apegnin & 36.11 \\
7-OH flavone & 8.48 \\
\hline
\end{tabular}


Table (4) Effect of Cupressus sempervirens leaves extracts on liver function and lipid profile of albino rats induced hepatic damage with paracetamol.

\begin{tabular}{|c|c|c|c|c|c|c|c|c|c|c|c|c|c|}
\hline \multirow[t]{2}{*}{ Group } & \multirow[t]{2}{*}{ Treatment } & \multirow{2}{*}{$\begin{array}{l}\text { AST } \\
(\mathrm{U} / \mathrm{L})\end{array}$} & \multirow{2}{*}{$\begin{array}{l}\text { ALT } \\
(\mathrm{U} / \mathrm{L})\end{array}$} & \multirow{2}{*}{$\begin{array}{l}\text { ALP } \\
(\mathrm{U} / \mathrm{L})\end{array}$} & \multicolumn{2}{|c|}{ Bilirubin(mg/dl) } & \multirow{2}{*}{$\begin{array}{l}\text { Total } \\
\text { protein } \\
(\mathrm{g} / \mathrm{dl})\end{array}$} & \multirow{2}{*}{$\begin{array}{l}\text { Albumin } \\
\text { (g/dl) }\end{array}$} & \multirow{2}{*}{$\begin{array}{l}\text { Globulin } \\
\text { (g/dl) }\end{array}$} & \multirow{2}{*}{$\begin{array}{l}\text { Triglyceride } \\
(\mathrm{mg} / \mathrm{dl})\end{array}$} & \multirow{2}{*}{$\begin{array}{c}\text { Total } \\
\text { cholesterol } \\
(\mathrm{mg} / \mathrm{dl})\end{array}$} & \multirow{2}{*}{$\begin{array}{c}\text { HDL- } \\
\text { Cholesterol } \\
(\mathrm{mg} / \mathrm{dl})\end{array}$} & \multirow{2}{*}{$\begin{array}{c}\text { LDL- } \\
\text { Cholesterol } \\
(\mathrm{mg} / \mathrm{dl})\end{array}$} \\
\hline & & & & & Total & Direct & & & & & & & \\
\hline 1 & $\begin{array}{l}\text { Negative control } \\
\text { (Normal Diet) }\end{array}$ & $\begin{array}{l}98 \pm \\
0.12^{\mathrm{d}}\end{array}$ & $\begin{array}{c}36 \\
\pm 0.11^{\mathrm{e}}\end{array}$ & $\begin{array}{l}282.14 \\
\pm 5.62 \mathrm{c}\end{array}$ & $\begin{array}{l}0.37 \pm \\
0.02^{\mathrm{e}}\end{array}$ & $\begin{array}{c}0.10^{ \pm} \\
0.01^{\mathrm{e}}\end{array}$ & $\begin{array}{l}6.12 \pm \\
0.04^{\mathrm{a}}\end{array}$ & $\begin{array}{c}3.16 \pm \\
0.01^{\mathrm{a}}\end{array}$ & $\begin{array}{l}2.96 \pm \\
0.04^{\mathrm{a}}\end{array}$ & $35.67 \pm 0.81^{\mathrm{b}}$ & $59.00 \pm 0.69^{d}$ & $47.14 \pm 1.06^{\mathrm{a}}$ & $5.17 \pm 1.05^{\mathrm{g}}$ \\
\hline 2 & $\begin{array}{l}\text { Positive control } \\
\text { (paracetamol } 750 \\
\text { mg. } \mathrm{kg}^{-1} \text { ) }\end{array}$ & $\begin{array}{l}214.57 \\
\pm 1.04^{\mathrm{a}}\end{array}$ & $\begin{array}{l}61.03 \\
\pm 0.5^{\mathrm{a}}\end{array}$ & $\begin{array}{l}505.00 \\
\pm 5.35^{\mathrm{a}}\end{array}$ & $\begin{array}{c}0.84 \pm \\
0.02^{\mathrm{a}}\end{array}$ & $\begin{array}{c}0.29 \pm \\
0.01^{\mathrm{a}}\end{array}$ & $\begin{array}{l}5.10^{ \pm} \\
0.04^{\mathrm{g}}\end{array}$ & $\begin{array}{l}2.75^{ \pm} \\
0.05^{c}\end{array}$ & $\begin{array}{l}2.35 \pm \\
0.08^{\mathrm{e}}\end{array}$ & $42.79 \pm 0.83^{\mathrm{a}}$ & $78.29 \pm 1.51^{\mathrm{a}}$ & $31.43 \pm 0.84^{\mathrm{d}}$ & $38.30 \pm 1.37^{\mathrm{a}}$ \\
\hline 3 & $\begin{array}{l}\text { Cupressus } \\
\text { sempervirens } \\
100 \mathrm{mg} \cdot \mathrm{kg}^{-1}+ \\
\text { paracetamol } 750 \\
\mathrm{mg} \cdot \mathrm{kg}^{-1}\end{array}$ & $\begin{array}{c}95.87 \pm \\
0.78^{\mathrm{e}}\end{array}$ & $\begin{array}{r}38.99 \\
\pm 0.29^{\mathrm{c}}\end{array}$ & $\begin{array}{l}274.57 \\
\pm 7.91^{\mathrm{e}}\end{array}$ & $\begin{array}{l}0.44 \pm \\
0.02^{b}\end{array}$ & $\begin{array}{l}0.18 \pm \\
0.01^{\mathrm{b}}\end{array}$ & $\begin{array}{l}5.99 \pm \\
0.03^{\mathrm{c}}\end{array}$ & $\begin{array}{l}3.18 \pm \\
0.00^{\mathrm{a}}\end{array}$ & $\begin{array}{c}2.81 \\
\pm 0.04^{\mathrm{c}}\end{array}$ & $33.86 \pm 1.12^{\mathrm{g}}$ & $59.29 \pm 0.42^{\mathrm{d}}$ & $46.43 \pm 0.95^{\mathrm{b}}$ & $6.09 \pm 0.81^{\mathrm{f}}$ \\
\hline 4 & $\begin{array}{l}\text { Cupressus } \\
\text { sempervirens } \\
200 \mathrm{mg} \cdot \mathrm{kg}^{-1}+ \\
\text { paracetamol } 750 \\
\text { mg.kg-1 }\end{array}$ & $\begin{array}{c}94.40 \pm \\
0.82^{\mathrm{f}}\end{array}$ & $\begin{array}{l}36.46 \\
\pm \underset{\text { de }}{0.63}\end{array}$ & $\begin{array}{l}258.29 \\
\pm 7.78^{g}\end{array}$ & $\begin{array}{l}0.38 \pm \\
0.01 \mathrm{de}\end{array}$ & $\begin{array}{l}0.13 \pm \\
0.01^{\mathrm{cd}}\end{array}$ & $\begin{array}{l}5.94^{ \pm} \\
0.04^{d}\end{array}$ & $\begin{array}{l}3.08 \pm \\
0.03^{\mathrm{ac}}\end{array}$ & $\begin{array}{l}2.86 \pm \\
0.04^{\mathrm{b}}\end{array}$ & $34.86 \pm 0.34^{\mathrm{d}}$ & $60.57 \pm 0.92^{\mathrm{c}}$ & $45.14 \pm 0.88^{c}$ & $8.46 \pm 0.18^{\mathrm{d}}$ \\
\hline
\end{tabular}


Table (5) Effects of Cupressus sempervirens leaves extracts antioxidant markers of rats having paracetamol induced hepatic damage

\begin{tabular}{|c|c|c|c|c|c|c|}
\hline Group & Treatment & $\begin{array}{l}\text { Glutathione } \\
\text { peroxidase } \\
\text { (U/g tissue) }\end{array}$ & $\begin{array}{l}\text { Glutathione -S- } \\
\text { transferase } \\
\text { (U/g tissue) }\end{array}$ & $\begin{array}{l}\text { Glutathione } \\
\text { Reduced } \\
\text { ( } \mu \mathrm{mol} / \mathrm{g} \\
\text { tissue) } \\
\end{array}$ & $\begin{array}{c}\text { Catalase } \\
\left(\mu M \mathrm{H}_{2} \mathrm{O}_{2} / \mathrm{Sec} / \mathrm{g}\right. \\
\text { wt tissue })\end{array}$ & $\begin{array}{l}\text { Nitric oxide } \\
(\mu \mathrm{mol} / \mathrm{L})\end{array}$ \\
\hline 1 & $\begin{array}{l}\text { Negative control } \\
\text { (Normal Diet) }\end{array}$ & $193.60 \pm 0.06^{\mathrm{g}}$ & $4.26 \pm 0.00^{\mathrm{b}}$ & $83.60 \pm 0.06^{\mathrm{f}}$ & $582.80 \pm 0.06^{\mathrm{d}}$ & $16.40 \pm 0.06^{\mathrm{e}}$ \\
\hline 2 & $\begin{array}{l}\text { Positive control } \\
\text { (paracetamol } 750 \\
\mathrm{mg} \cdot \mathrm{kg}^{-1} \text { ) }\end{array}$ & $171.40 \pm 0.06^{\mathrm{f}}$ & $4.0 \pm 0.06^{\mathrm{d}}$ & $54.10 \pm 0.06^{\mathrm{g}}$ & $566.03 \pm 0.03^{d}$ & $48.90 \pm 0.06^{\mathrm{a}}$ \\
\hline 3 & $\begin{array}{l}\text { Cupressus } \\
\text { sempervirens } 100 \\
\text { mg.kg-1+ } \\
\text { paracetamol } 750 \\
\text { mg.kg-1 }\end{array}$ & $286.20 \pm 0.06^{\mathrm{a}}$ & $4.39 \pm 0.00^{]}$ & $150.60 \pm 0.06^{\mathrm{a}}$ & $818.00 \pm 0.58^{\mathrm{a}}$ & $27 \pm 0.06^{\mathrm{c}}$ \\
\hline 4 & $\begin{array}{l}\text { Cupressus } \\
\text { sempervirens } 200 \\
\text { mg.kg-1 } \\
\text { paracetamol } 750 \\
\text { mg.kg-1 }\end{array}$ & $250.00 \pm 0.58^{c}$ & $4.29 \pm 0.00^{\mathrm{b}}$ & $131.50 \pm 0.06^{\mathrm{c}}$ & $725.60 \pm 0.06^{\mathrm{b}}$ & $26.10 \pm 0.06^{\mathrm{d}}$ \\
\hline
\end{tabular}

\section{DISCUSSION}

Liver diseases remain one of the serious problems throughout the world (Pushpavalli et al., 2010). The impairment of liver is multifactorial where it may result from viral or protozoal infection, chronic use of alcohol, drugs and other xenobiotics (Farghali et al., 2009).Today ,millions of people worldwide suffer from various hepatic disorders .Among these hepatic disorders , acute and viral hepatitis are the prevalent and occur in many countries (Manna et al., 2007). The present study was undertaken to explore the potential hepatoprotective effect of natural compound (Cupressus sempervirens) against experimentally induced liver damage in the current study liver damage induced by paracetamol. It is well known that paracetamol exerts its hepatotoxic effect in dose depended manner. However, there are many mechanisms illustrate how paracetamol induced it is hepatotoxicity (Cover et al., 2006; Grypioti et al., 2006). In the present study, administration of paracetamol caused elevation in AT,ALT,ALP ,total bilirubin and direct bilirubin compared with control normal group and treated group with Cupressus sempervirens this is in agreement with previous data (El-Alfy et al., 2014)Which could be taken as an index of liver damage.

In our study, the rise in AST and ALT levels of activities induced by paracetamol administration was significantly reduced by administration of Cupressus sempervirens. protective activity might be due its effect against cellular leakage and loss of functional integrity of cell membrane in hepatocytes. The increase in the activities of AST and ALT in serum of rats treated by paracetamol might be due to increased permeability of plasma membrane or cellular necrosis leading to leakage of the enzymes to the blood stream (Rao and Das, 2014).

ALP is excreted normally via bile by the liver, The liver injury due to toxin can result in defective execration of bile by hepatocytes which are reflected as increase ALP level in serum (Girish et al., 2009; Rajesh and Latha, 2004) throughout the current study administration of paracetamol resulted in significant increase in serum AST, ALT,ALP activities, total bilirubin and direct bilirubin due to damage of structural integrity of hepatocytes as stated by Wang et al. (2008). Moreover it could be also related to cholestasis (Gordillo et al., 2007). In contrast, an increase in ALP activity and bilirubin level reflect the pathological alteration in biliary flow, increase in serum total bilirubin and direct bilirubin concentration after paracetamol administration might be attributed to normal uptake,conjugation and excretion by the damage hepatic parenchyma (Wang et al., 2008). Significant decrease in total protein, albumin and globulin due to disorder in synthetic function of liver (Ogutcu et al., 2008) our results referred that Cupressus sempervirens improve the level of serum total protein ,albumin and globulin due to high polyphenolic content, thus antioxidant properties of this plant due to its capacity to restore the functionality of the hepatic cell and reduce endoplasmic reticulum oxidation stress (Hashemi et al., 2013), globulin 
improvement may be due to its immune stimulatory effect (Ross and Pawlina, 2011). Our study showed that paracetamol toxicity induced hypercholesterolemia with increased triglycerides and (LDLC) and reduced (HDLC). Sirag (2007) mentioned that treatment with the plants extract result in reduce cholesterol may be due to inhibiting the enzyme (HMG-COA) (the main enzyme in cholesterol biosynthesis and by promoting LDL degradation. Moreover, Tahmasbi et al. (2013) attributed the decreased cholesterol level to the increased excretion in faces reduced absorption with oxidative modification of lipoprotein especially LDL resulted from the high antioxidant effect. The obtained data demonstrated in table (5) revealed that, administration of paracetamol to normal rats exhibited a significant reduction in GSH, glutathione-s-transferase ,glutathione peroxidase and catalase enzyme activities the result are in agreement with the recorded data of Durairaj et al. (2008) who reported that paracetamol at dose above therapeutic dose to normal rats led to a marked reduction in GSH, Glutathione -s-transferase ,glutathione peroxidase and catalase enzyme activities this result are in agreement with the recorded data of Durairaj et al. (2008) who reported that paracetamol at dose above therapeutic dose to normal rats led to a marked reduction in GSH, Glutathione-stransferase, glutathione peroxidase and catalase enzyme activities, these enzymes have been shown to protect hepatocytes against lipid peroxidation or inflammation preventing occurrence of hepatic necrosis (Jia et al., 2012). Reduced glutathione (GSH) level significantly reduced might attributed to inhibition of its generating enzymes(GSH-RX) by paracetamol GSH is regenerated from oxidizing glutathione (GSSG) and NADPH in a reaction catalyzed by (GSH-RX) the deficiency of GSH may be attributed to a deficiency in G6PD which is considered a house heaping enzyme that catalyzes the first step in pentose phosphate pathway it produces NADPH which is necessary for reduction of (GSSG) by(GSH-Rx)to GSH and this completely agree with Sirag (2007). So, the depletion of GSH. Seems to be prime factor that permits lipid peroxidation (Ahmed and Ali, 2010). In this study the damage effect resulted from paracetamol was defeated with the use of Cupressus sempervirens as relived the reduction in GSH, glutathione-s-transferase, glutathione peroxidase and catalase that cased by paracetamol and the consequent oxidative damage to liver present study agree with El-Alfy et al. (2014) who has found that this plant leaves extract preserved that structural integrity of hepatocyte compared with paracetamol that evoke necrosis, fatty degeneration compared with paracetamol that evoke necrosis, fatty degeneration and inflammatory cell infiltration. This plant leaves extract is the source of bioactive compound that have been shown to scavenge free radical and decrease macrophage oxidative stress and lipid peroxidation (Tahmasbi et al., 2013). The obtained data demonstrated in table (5) revealed administration of paracetamol to normal rats exhibited a significant increase in liver nitric oxide concentration when compared to control normal group, nitric oxide is signaling molecule that plays a key role in the pathogenesis of inflammation and its over produced in abnormal physiological conditions (Gong et al., 2010). The unbalance between the oxidant species and the antioxidant defense system may trigger specific factors responsible for oxidative damage in cell (Piososchi and pop, 2015). Lipid are the most involved class of biomolecules, lipid oxidation give rise to a number of secondary products, these products are mainly aldehydes (Uchida, 2000). Our study revealed reduction of nitric oxide after treatment of Cupressus sempervirens leaves extract.

\section{Conclusion}

In conclusion, the finding of the present study demonstrated that Cupressus sempervirens administration provided on effective protection against hepatotoxicity and oxidative damage in liver induced by paracetamol in rats since these natural antioxidant agent were able to ameliorate serum biomarkers of hepatic function, enzymatic antioxidant defense system, prevent the lipid peroxidation and oxidative stress in hepatic tissues

\section{Acknowledgements}

We acknowledge MERC., Fac. of Medicine, Mansoura University for its support

\section{REFERENCES}

Ahmed, M., Ali, S.E., 2010. protective effect of pomegranate peel ethanol extract against ferric nitrilotriacetate induced renal oxidative damage in rats. Journal of Cell and Molecular Biology 7, 35-43.

Bock, P.P., Karmer, R., Paverka, M., 1980. A simple assay for catalase determination Cell Biol Monogr 7 44-74.

Cover, C., Liu, J., Farhood, A., Malle, E., Waalkes, M.P., Bajt, M.L., Jaeschke, H., 2006. Pathophysiological role of the acute inflammatory response during 
acetaminophen hepatotoxicity. Toxicol Appl Pharmacol 216, 98-107.

Doumas, B.T., 1975. Standard methods of protein determination. Clin. Chem. 7, 175-188.

Doumas, B.T., Biggs, H.G., Arends, R.L., Pinto, P.V.C., 1971. Albumin standard and the measurement of serum albumin with bromocresol green. Clin. Chem. Acta. 31, 87-95.

Durairaj, A.S., Vaiyapuri, T.S., Kanti, M.U., Malaya, G.U., 2008. Protective activity and antioxidant potential of Lippia nodiflora extract in paracetamol induced hepatotoxicity in rats. Iranian Journal of Pharmacology and Therapeutics 7, 83-89.

El-Alfy, N.Z., Ahmed, H.H., Mahmoud, M.F., Yahysa, S.M., 2014. Regression of liver fibrosis by punica granatum peel extract in the experimental model. World Journal of Pharmacy and Pharmaceutical Sciences 3, $22-44$.

Emami, S.A., Tayarani-Najaran, Z., Ghannad, M.S., Karamadini, P.K., Karamadini, M.K., 2009. Antiviral Activity of Obtained Extracts from Different Parts of Cupressus sempervirens against Herpes Simplex Virus Type 1. Iranian Journal of Basic Medical Sciences 12, 133-139.

Farghali, H., Cerny, D., Kamenikova, L., Martinek, J., Horinek, A., Kmonickova, E., Zidek, Z., 2009. Resveratrol attenuates lipopolysaccharide-induced hepatitis in Dgalactosamine sensitized rats: role of nitric oxide synthase 2 and heme oxygenase-1. Nitric Oxide 21, 216-225.

Fossati, P., Precipe, L., 1982. The determination of triglycerides using enzymatic method Clin. Chem. 28, 2077.

Girish, C., Koner, B.C., Jayanthi, S., Ramachandra Rao, K., Rajesh, B., Pradhan, S.C., 2009. Hepatoprotective activity of picroliv, curcumin and ellagic acid compared to silymarin on paracetamol induced liver toxicity in mice. Fundam Clin Pharmacol 23, 735-745.

Gong, G.H., Qin, Y., Huang, W., Zhou, S., Yang, X.H., Li, D., 2010. Rutin inhibits hydrogen peroxide-induced apoptosis through regulating reactive oxygen species mediated mitochondrial dysfunction pathway in human umbilical vein endothelial cells. European Journal of Pharmacology 628, 2735.

Gordillo, K.R., Segovia, J., Shibayama, M., Vergara, P., Moreno, M.G., Muriel, P., 2007. Curcumin protects against acute liver damage in the rat by inhibiting NF-
$\mathrm{Kb}$,proinflammatory cytokines production and oxidative stress. Biochimica et Biophysica Acta. 1770, 989-996.

Grypioti, A.D., Theocharis, S.E., Demopoulos, C.A., Papadopoulou-Daifoti, Z., Basayiannis, A.C., Mykoniatis, M.G., 2006. Effect of platelet-activating factor (PAF) receptor antagonist (BN52021) on acetaminophen-induced acute liver injury and regeneration in rats. Liver Int 26, 97105.

Habig, W.H., Pabst, M.J., Jakoby, W.B., 1974. Glutathione S-transferases. The first enzymatic step in mercapturic acid formation. J Biol Chem 249, 7130-7139.

Hashemi, K., Parivar, K., Fazlifar, S., Haghparast, A., Mohri, M., Azghadi, N.M., Shirazi, M.N., Afkhami-Goli, A., 2013. Pomegranate (Punica granatum L.) reduces endoplasmic reticulum stress induced by renal ischemia/reperfusion injury in rat. Turkish Journal of Biology 37, 464-471.

Jia, R., Cao, L., Xu, P., Jeney, G., Yin, G., 2012. In vitro and in vivo hepatoprotective and antioxidant effects of Astragalus polysaccharides against carbon tetrachloride-induced hepatocyte damage in common carp (Cyprinus carpio). Fish Physiol Biochem 38, 871-881.

Kassem, F.F., Harraz, F.M., El-Sebakhy, N.A., De Pooter, H.L., Schamp, N.M., Abou-Shleib, H., 1991. Composition of the essential oil of EgyptianCupressus sempervirens L. cones. Flavour and Fragrance Journal 6, 205-207.

Lee, J.C., Kim, H.R., Kim, J., Jang, Y.S., 2002. Antioxidant property of an ethanol of the stem of Opuntia ficu-indicavar. Saboten. J. Agric. and Food Chem. 50, 6490-6496.

Manna, P., Sinha, M., Sil, P.C., 2007. Protection of arsenic-induced hepatic disorder by arjunolic acid. Basic Clin Pharmacol Toxicol 101, 333-338.

Montgomery, H.A.C., Dymock, J.F., 1961. Colorimetric determination of nitric oxide. Analyst, 86, 414-417.

Moron, M.S., Depierre, J.W., Mannervik, B., 1979. Levels of GSH, GR and GST activities in rat lung and liver. Biochimica et Biophysica Acta 582, 67-78.

Ogutcu, A., Suludere, Z., Kalender, Y., 2008. Dichlorvos-induced hepatotoxicity in rats and the protective effects of vitamins $\mathrm{C}$ and E. Environ Toxicol Pharmacol 26, 355-361.

Om, P., 2011. Clinical biochemistry of hepatotoxicity. Journal of Clinical Toxicology, 67-70. 
Piososchi, A.M., pop, A., 2015. The role of antioxidants in the chemistry of oxidative stress. A review Eur. J. Med. Chem. 97, 55 -74 .

Prakash, D., Singh, B.N., Upadhyay, G., 2007. Antioxidant and free radical scavenging activities of phenols from onion (Allium cepa). Food Chemistry 102, 1389-1393.

Prins, H.K., Loos, J.A., 1969. Determination of energy-rich phosphate, 2, 3diphosphoglycerate, lactate, and glutathione in small amounts of blood cells. Adv Auto Anal 1, 285-291.

Pushpavalli, G., Kalaiarasi, V., Veeramani, C., Pugalendi, K.V., 2010. Effect of chrysin on hepatoprotective and antioxidant status in Dgalactosamine-induced hepatitis in rats. Eur. J. Pharmacol 631, 36-41.

Rajesh, M.G., Latha, M.S., 2004. Preliminary evaluation of the antihepatotoxic activity of kamilari, a polyhedral formulation. J. Ethnopharmacol. 91, 99-104.

Rao, S., Das, K., 2014. Hepatoprotective and antioxidant activity of Lannea coromandelica Linn. on thioacetamide induced hepatotoxicity in rats. International Letters of Natural Sciences 3, 66-72.

Reeves, P.G., Nielsen, F.H., Fahey, G.C., Jr., 1993. AIN-93 purified diets for laboratory rodents: final report of the American Institute of Nutrition ad hoc writing committee on the reformulation of the AIN-76A rodent diet. J Nutr 123, 1939-1951.

Reitman, S., Frankel, S., 1957. A colorimetric method for the determination of serum glutamic oxaloacetic and glutamic pyruvic transaminases. Am. J. Clin. Path. 221, 56.

Ross, M.H., Pawlina, W., 2011. Digestive system 111: Liver, Gall bladder and Pancreas. In: Histology: A text and atlas (Ross, M.H. and
Pawlina, W. eds), 4th ed. Lippincott Williams \& Wilkins, Philadelphia.

SAS, 1996. SAS Procedure Guide. "Version 6.12 Ed.". SAS Institute Inc., Cary, NC, USA.

Singh, B.N., Singh, B.R., Singh, R.L., Prakash, D., Sarma, B.K., Singh, H.B., 2009. Antioxidant and anti-quorum sensing activities of green pod of Acacia nilotica L. Food Chem Toxicol 47, 778-786.

Singleton, V.L., Rossi, J.A., 1965. Colorimetry of total phenolics with phosphomolybdicphosphotungestic acid reagents. Am. J. Enol. Vitic 16, 144-158.

Sirag, H.M., 2007. Biochemical studies on thioacetamide toxicity in male albino rats and the role of tomato juice as an antioxidant. Mansoura J Forensic Med Clin Toxicol 15, 90-114.

Tahmasbi, S., Heidarpour, M., Kazemi, M.H., 2013. Effects of pomegranate seed oil on oxidative stress parameters and lipid profiles in ovariectomized rats. Iranian Journal of Veterinary Surgery 8, 17-24.

Tietz, N.M., 1983. Textbook of clinical chemistry. W.B. sunders Co. .

Uchida, K., 2000. Role of reactive aldehyde in cardiovascular diseases. Free Radic Biol Med 28, 1685-1696.

Wang, H.J., Tashiro, S., Onodera, S., Ikejima, T., 2008. Inhibition of insulin-like growth factor 1 receptor signaling enhanced silibinininduced activation of death receptor and mitochondrial apoptotic pathways in human breast cancer MCF-7 cells. J Pharmacol Sci 107, 260-269.

Zeinab, Y.A., Atia, H., Ibrahi, N., 2012. Possible Hepatoprotective Potential of Cynara scolymus, Cupressus sempervirens and Eugenia jambolana Against ParacetamolInduced liver Injury: In-vitroand In-vivo Evidence. Nature and Science 10, 75-86. 